\title{
Tropical diseases in health science
}

\author{
Katarzyna Van Damme-Ostapowicz ${ }_{\text {B,D,E,F }}^{1}$ Elżbieta Krajewska-Kułak ${ }_{\text {E,F, }}^{1}$ \\ Dorota Kaczerska ${ }_{\text {F }}^{2}$, Mariusz Kozakiewicz ${ }^{3}$ E
}

${ }^{1}$ Department of Integrated Medical Care Medical University of Białystok

2 Department of Clinical Nutrition Medical University of Gdańsk

${ }^{3}$ Nicolaus Copernicus University Collegium Medicum Department of Food Chemistry, Bydgoszcz

\begin{abstract}
The rapidly growing number of travelers covering global distances is a well-known fact. According to current data from the World Tourism Organization, over 150 million travelers visit developing countries every year, including 52 million people traveling to South Asia and Oceania, 31 million to Africa and approx. 37 million to America. It is estimated that in Poland, more than million Poles a year travel to tropical countries for work or tourism, and this number is growing.

The consequence of increased tourist or occupational traffic, population migration or deployment of military troops, is the increased risk of occurrence of tropical diseases in other regions. Currently, due to the warming of climate at a global scale (so-called greenhouse effect), epidemiological situation with regard to tropical diseases is changing. At more and more new areas, beyond that zone, diseases specific for tropical zones occur, e.g. Chikungunya fever in northern Italy or Dengue hemorrhagic fever (DHF) in Turkey.

Travel medicine is a new branch of medical science responding to the need for making specific knowledge available for travelers and healthcare professionals. The number of travelling children - even the youngest infants - is also growing. Therefore, healthcare professionals have to pay more attention to travel-related problems and a professional approach to tourists/patients, which enables the prevention of numerous diseases and the threat of dissemination of diseases - sometimes fatal - throughout populations.
\end{abstract}

Keywords: health education, tropical diseases, travel medicine

\section{Introduction}

According to the World Tourism Organisation (UNWTO, United Nations World Tourism Organization) the number of international journeys nearly doubled over the last decade [1]. World trends are reflected by the following comparison: in 2005 there were over 800 million foreign journeys, and 50 years before the number was 15 times lower. Dangers associated with newly discovered infectious pathogens or concerns related to international terrorism are not able to reduce the rapid pace of development of tourism. It is estimated that in 2020 the number of international journeys will exceed 1.5 billion [1].

In the past hundred and fifty years the time needed to circumnavigate the globe has fallen from about a year to just a few dozen hours, and the development of transport technology and increasing globalization have contributed to the dramatic increase in the number of travelers at the turn of the last century and the beginning of the present one $[1,2]$.
It is also expected that the number of trips to developing countries will significantly increase [1]. That applies especially to Asian, Middle East, African and Pacific Island countries - regions characterized by a particularly low sanitation level and a high threat of infectious and parasitic diseases typical for the warm climate. Therefore, concerns about the health of travelers from our climatic zone are justified [1].

The above mentioned phenomena have led to the foundation and development of travel medicine, a new, interdisciplinary field of medical science [3].

The first world conference on that subject was organized under the auspices of the World Health Organization (WHO) and UNWTO in 1988 [4]. That period was the beginning of massive international tourism in Poland. Previously, imposed prohibitions and limitations prevented Polish people from traveling around the world. That situation surely affects the current circumstances of travel medicine in Poland. It is also a significant fact that Poland did not have any foreign colonies or 
close relations to tropical regions. At present, however, world tourism trends are also present in Poland. Various factors, e.g. increasing wealth and EU membership have made international travel available for many Polish citizens $[1,4]$.

At present, not only the number of tourists has increased, but their demographic profile has also changed. The number of children, elderly and chronically ill people travelling abroad is rising. considerate should be noted that international journeys are undoubtedly associated with increased health risk, especially in the case of a trip to tropical regions with a low sanitation level [1]. Travelling to the tropics should be carefully considered and planned, and recommendations should include the following: information about the region and its environment; climatic conditions and weather during the particular season of year; character and length of stay; dwelling conditions (hotel, bungalow, tent, access to fresh or running water, etc); the age of the traveler; coexisting diseases and possible local threats, which are sometimes hard to foresee $[5,6]$. Appropriate clothes and footwear, which protect against getting too hot or cold, bites or stings of dangerous insects (mosquitoes), bugs, spiders and higher animals are essential [6].

The decision to go on an exotic journey is often made impulsively, under the influence of suggestive ads and last-minute offers. Therefore they are often realized without appropriate medical preparation and knowledge of local health threats.

Unfortunately, scientific literature contains only few papers related to the issues of travel medicine in the professional practice of a physiotherapist, nurse, midwife or medical rescuer, and teaching programs for students in those fields also lack those subjects.

\section{Material and methods}

This is a review. It is based on World Heath Organisation's (WHO) reports, and studies and papers published by the authors who had had direct or indirect contact with the problem of "tropical diseases in health science", or who had carried out research on that subject.

\section{Results}

Travelling is a change of environment that is inseparable from the health-related risk both during the travel and the stay abroad. The risk depends on the traveler's health condition (physical and emotional fitness), travel and residence conditions, and the awareness of existing threats $[3,7]$.

The interdisciplinary character of travel medicine is incomparable to any other fields of medical science. It is a new branch of medical science, located between the sciences of infectious diseases, epidemiology, hygiene, internal medicine, pediatrics, surgery and traumatology. It deals with the broadly understood health aspects of a travel.
Travel medicine covers not only health-related risks caused by infectious pathogens, but also an evaluation of the influence of environmental changes, climatic conditions, diet, habits, etc. on the traveler's health. Issues of health prophylaxis in people travelling to tropical countries are an important part of travel medicine. Experts in travel medicine offer their advice on protective vaccinations, inform tourists of the specific threats and promote the international vaccination form. The field is closely related to all specializations ensuring the quality of life in health and disease [3].

The exponential progress of medical knowledge, also in the field of tropical medicine, shows the need for the exchange of experience and interdisciplinary cooperation [3,7].

The above mentioned facts and our studies clearly indicate that specific medical problems associated with a stay in a different climate and sanitary conditions are occurring more and more commonly. The prevalence of imported diseases is increasing accordingly.

Healthcare professionals are the most easily accessible source of information for patients. Therefore their influence on the education of travelers is a great one.

\section{Discussion}

The world is sometimes referred to as a global village, and trips to tropical countries are becoming more and more popular [8,9]. Many Polish citizens travel to the tropics every year for business or pleasure. The majority of them have no knowledge of the health -related threats which are present in their destinations even though it is obvious that the tropical climate generates many various dangers for human health and life. Those dangers are related both to a specific microclimate and local flora and fauna [5].

There is no doubt that travel broadens the mind and offers some unforgettable experiences. However, a hot climate and poor sanitary conditions pose the threat of various diseases characteristic for the different climatic zone [10].

Patient education is a process involving teaching and learning, directed at a patient and/or their environment. It is a process, which means subsequent, logically and causatively linked actions taken in order to cause a change in the patient's behaviour. The purpose of the patient's education is influencing attitudes, beliefs and the motivation of the patient through the shaping of appropriate health-related behaviour and the sense of responsibility for one's wellbeing [11]. Recently, some changes in the healthcare professionals' tasks have been observed in health sciences. Besides the traditional roles involving patient care and performing medical recommendations, some new tasks have appeared, involving, among others, health education, advice and promotion [12].

Nurses and students of nursing want to educate patients and to expand their knowledge in the field 
of travel medicine and tropical medicine; and patients possess an insufficient level of knowledge in prophylaxis associated with a trip to another climatic zone and low living standards. The above statements are based on our study completed in the Podlaskie voivodship $[13,14,15,16]$. Our studies also indicate that there are certain obstacles associated with the lack of appropriate knowledge of travel medicine, caused by an educational gap in the process of nursing education $[13,14,15,16]$.

Curricula realized in the faculties of nursing do not involve classes on the subject of travel medicine. There are also no modern textbooks for students of Health Sciences that would explain some problems in the fields of travel medicine and tropical medicine, including etiology, symptoms, dissemination pathways, therapy and prevention.

It is important for healthcare professionals, who increasingly often face clients/patients preparing for a long journey or returning home from abroad, to have an appropriate and useful knowledge in that field.

\section{Conclusions}

Therefore, healthcare professionals have to pay more attention to travel-related problems and a professional approach to tourists/patients, which enables the prevention of numerous diseases and the threat of dissemination of diseases - sometimes fatal - throughout populations. Therefore their influence on the education of travelers is a great one.

\section{References:}

1.Wroczyńska A., Nahorski W.L. Dynamika ruchu turystycznego w Polsce i na świecie oraz zagrożenia z nią związane. Dynamism of Tourism in Poland and the World and the Related Risks. Zakażenia 2009; 2: 4-8.

2. LaRocque R.C., Rao S.R., Tsibris A., Lawton T., Barry A.M., Marano N., Brunette G., Yanni E., Ryan E.T. Pre -travel Health Advice-Seeking Behavior Among US International Travelers Departing From Boston Logan International Airport. J. Travel. Med. 2010; 17(6): 387-391. 3. Prokopowicz D.. Rośliny trujące. Poisonous Plants. Venomous Animals. In: Travel Medicine. Białystok; Wydawnictwo Ekonomia i Środowisko. 2007, pp.13-19. 4. Tourism Development Strategy for the Sub-Carpathian Province for 2007-2013, Warsaw, Polish Tourism Development Agency. 2006, pp. 5-7, 13-17.

5. Simon K. Early Detection, Treatment and Prevention and Tropical Diseases. Przew. Lek. 2008; 1: 250-254. 6. Łyson S. In the Direction of Ensuring Global Health Safety - 60th World Health Assembly. Public Health 2007; 117: 495-500.
7. Prokopowicz D. Travel Medicine. Epidemiological Survey, 2003;57:335-9

8. Kacprzak E. Risks Associated with Travel to Tropical Countries. Kosmos, 2005; 54: 115-122.

9. Juckett G. Travel medicine 2005. W. V. Med. J. 2004; 100: 222-225.

10. Korzeniewski K. Współczesne operacje wojskowe. Modern Military Operations. Health Risks in Different Climate and Sanitary Conditions, Warszawa; WIM Wydawnictwo Akademickie Dialog: 2009, p 63-65.

11. Ciechaniewicz W. Pedagogical Activity of Nurses. In: Ciechaniewicz W., ed. Pedagogy. Warszawa;. PZWL: 2000, pp. 231- 232.

12. Jankowiak B., Krajewska-Kułak E., Niczyporuk W. Nursing Education Standard with Regard to Patients with Psoriasis. Dermatol. Klin.2005; 7(4): 192.

13. Van Damme-Ostapowicz K., Krajewska-Kułak E. Knowledge of Nursing Students in the Podlaskie Province in the Field of Travel Medicine: A Quantitative Study. Problemy Pielęgniarstwa, 2012; 3: 327-337.

14. Van Damme-Ostapowicz K. ,Krajewska-Kułak E., Flisiak R., Mięgoć H., Kowalczuk K. Health-related problems of People travelling to Countries in Different Climatic Zones - preliminary report. Pielęgniarstwo XXI wieku, 2012; 1 (38):35-40.

15. Van Damme-Ostapowicz K., Krajewska-Kułak E., Czygier M., Sarosiek J., Karolina Szpakowska-Żurawska K., Faliszewska E.M., Długołędzka K., Osipiuk A, Flisiak R., Mięgoć H. Analysis of the Causes of Hospitalisation in the Department of Infectious Diseases and Hepatology at the Medical University of Białystok After Returning from a Country with a Different Climate Zone in 2004-2009. Polski Przegląd Nauk o Zdrowiu, 2011; 3(28): 336-342.

16. Van Damme-Ostapowicz K, Krajewska-Kułak E, Olszański R, Nahorski L. Problems involving contagious diseases and tropical medicine - new challenges for health care staff. Advances in Clinical and Experimental Medicine, 2011; 20(4): 461-471.

\section{Correspondence address:}

dr n. med. Katarzyna Van Damme-Ostapowicz Kierownik: prof. dr hab. med. Elżbieta Krajewska-Kułak Zakład Zintegrowanej Opieki Medycznej Uniwersytet Medyczny w Białymstoku ul. M. Curie-Skłodowskiej 7a

15-096 Białystok, Poland

$\mathrm{Tel} /$ fax +48 85/ 7485528

email: katarzyna.ostapowicz@gmail.com 